[Agr. Biol. Chem., Vol. 34, No. 1, p. 149 151, 1970]

\title{
Nature of DNA and RNA Degradation in Escherichia coli Induced by Colicin $\mathrm{E}_{2}$
}

Sir:

Colicin $\mathrm{E}_{2}$, one of the bacteriocins produced by Enterobacteriacae, induces remarkable degradation of $\mathrm{DNA}^{1 /}$ and $\mathrm{RNA}^{2)}$ in sensitive strains of Escherichia coli. What kinds of DNase and RNase are responsible for these degradations are not yet known. Endonuclease $I$ and RNase I are known to be the main degradative enzymes for DNA and RNA in $E$. coli cells. However, genetic mutants defective for these enzymes, $E$. coli 1100 (endonuclease $\mathrm{I}^{-}$) and E. coli Q 13 (RNase $\mathrm{I}^{-}$), also showed considerable degradation of their own nucleic acids due to colicin $E_{2}$, which seemed to exclude the possibility of these enzymes being involved in the colicin action (Fig. 1). ${ }^{3 !}$

Nature of DNA and RNA degradation induced by colicin $\mathrm{E}_{2}$ was studied by zonal sedimentation analysis. Colicin $\mathrm{E}_{2}$ was prepared according to the procedure described by Beppu and Arima." ${ }^{41}$. coli K 12 W 2252 thy ${ }^{-}\left(\right.$met $\left.^{-}, \lambda^{8}\right)$ prelabeled with ${ }^{3} \mathrm{H}$-thymidine was challenged with colicin $\mathrm{E}_{2}$ at high multiplicity (about 50) and cells sampled at appropriate intervals were lyzed by treatments with lysozyme-EDTA and sodium dodecyl sulfonate. $^{5 /}$ The lysate was ultracentrifuged

1) M. Nomura, Cold Spring Harbor Symp. Quant. Biol., 28, 315 (1963).

2) K. Nose and D. Mizuno, Biochem. Biophys. Acta, 119, 639 (1966).

3) A. Yanai, T. Beppu and K. Arima, presented at the Annual Meeting of the Agricultural Chemical Society of Japan, Tokyo, April 4, 1969.

4) T. Beppu and K. Arima, J. Bacteriol., 93, 80 (1967).

5) E. M. Kutter and J.S. Wiberg, J. Mol. Biol., 38,395 (1968).

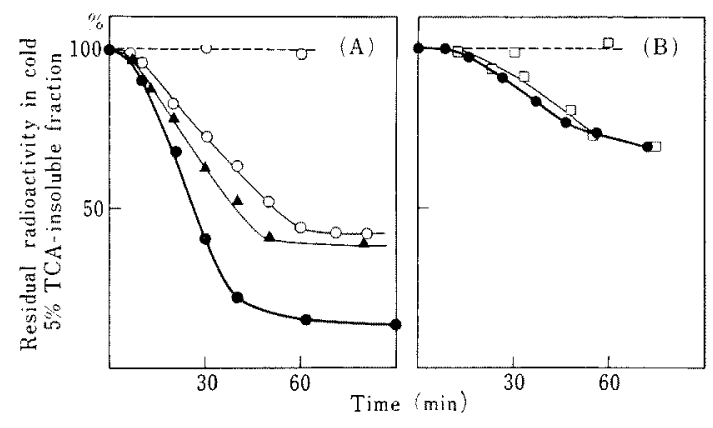

FIG. 1. Time Course of DNA and RNA Degradation.

Colicin $\mathrm{E}_{2}$ was added to the growing culture at $37^{\circ} \mathrm{C} 30 \mathrm{~min}$ after chasing of cells pre-labeled with ${ }^{3} \mathrm{H}-\mathrm{TdR}(\mathrm{A})$ or ${ }^{14} \mathrm{C}$-uracil (B). Samples were taken into equal volumes of cold 10\% TCA and residual radioactivities were counted.

- E. coli W 2252 thy-

O-O E. coli 1100

A-A E. coli B

$\square-\square$ E. coli Q 13

$0-\mathrm{O} E$. coli 1100 , no colicin $\mathrm{E}_{2}$ addition

$\square-\square$ E. coli $\mathrm{Q} 13$, no colicin $\mathrm{E}_{2}$ addition

through alkaline sucrose density gradient (5 $20 \%)$ and fractionated. Radioactivity in each fraction was measured by liquid scintillation spectrometer. As shown in Fig. 2, band of DNA shifted toward the top rapidly after the colicin challenge (average MW of DNA was calculated $^{6)}$ to decrease to $70 \%$ after $3 \mathrm{~min}$ and $35 \%$ after $7 \mathrm{~min}$ ). Sedimentation analysis at neutral $\mathrm{pH}$ also showed rapid decrease of average MW of DNA at early stage.

Seven minutes after the colicin challenge,

6) J. Abelson and C. A. Thomas, J. Mol. Biol., 18, 262 (1966). 


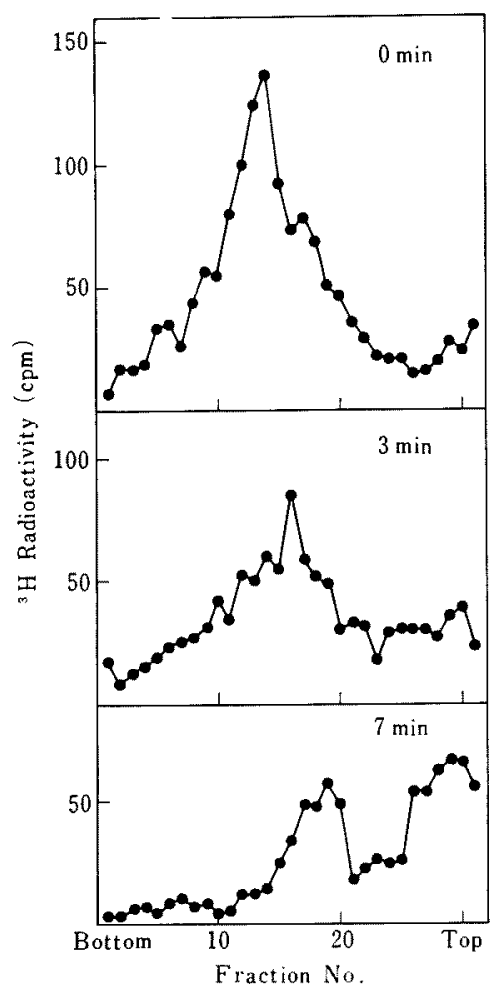

FIG. 2. Alkaline Sucrose Density-gradient Profile of ${ }^{3} \mathrm{H}-\mathrm{TdR}$ Labeled $E$. coli W 2252 thy- DNA at Various Stages during Degradation.

releasing of radioactivity into the cold acidextractable fraction reached only $5 \%$ of total activity originally present in DNA. These observations suggest that early stage of DNA degradation due to colicin $\mathrm{E}_{2}$ is endonucleolytic.

Zonal sedimentation analysis of RNA-degradation due to colicin $\mathrm{E}_{2}$ was carried out with $E$. coli $Q 13$ preliminary labeled with ${ }^{14} \mathrm{C}$-uracil. Cells were lyzed by lysozymeEDTA-SDS, and RNA was extracted by phenol method and ultracentrifuged through $1.5 \sim 15 \%$ sucrose density-gradient. ${ }^{7 \prime}$ As shown

7) E. H. McConkey, "Methods in Enzymology," Vol. XIIA, Academic Press, 1967, p. 620.

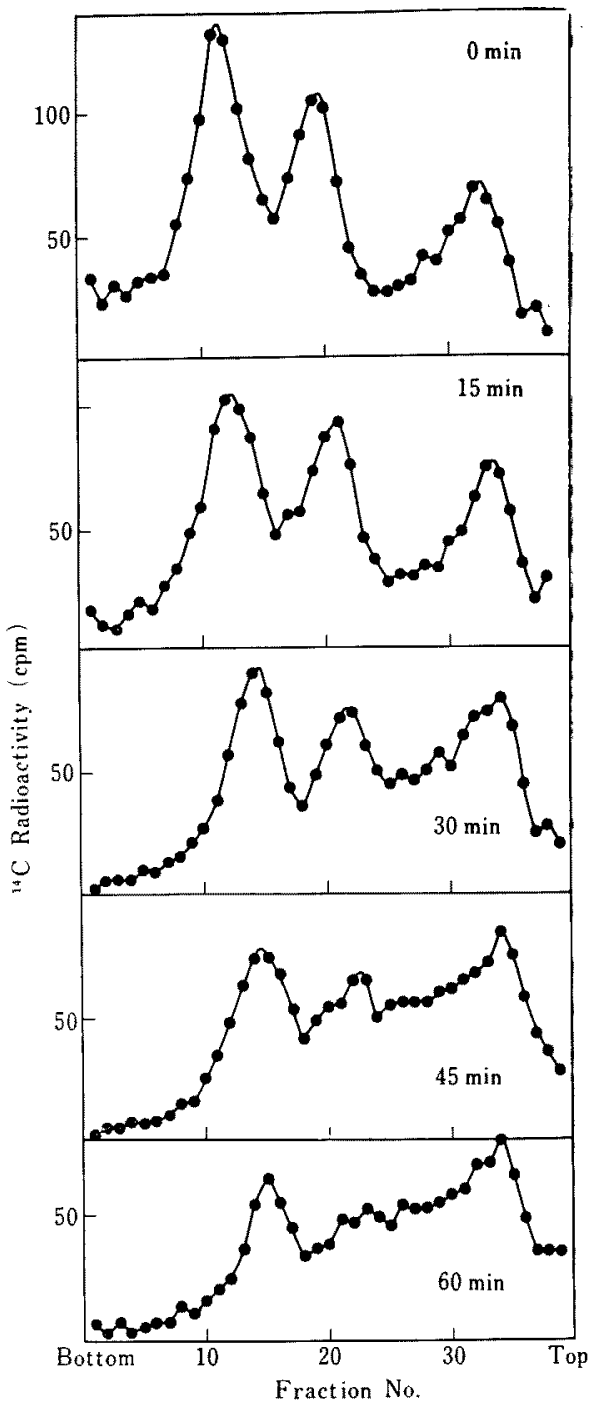

FIG. 3. Sucrose Density-gradient Profile of ${ }^{14} \mathrm{C}-$

Uracil Labeled E. coli $Q 13$ RNA at Various Stages during Degradation.

in Fig. 3, both $23 \mathrm{~s}$ and $16 \mathrm{~s}$ ribosomal RNA were degraded but residual RNA retained considerable size even $60 \mathrm{~min}$ after the colicin challenge.

These data suggest that some degradative enzyme(s), probably endonucleolytic one ex- 
cept endonuclease I and RNase I, may be

Akira YANAI

responsible for the early stage of nucleic acid

Teruhiko BEPPU degradation induced by colicin $\mathrm{E}_{2}$.

Kei Arima

Department of Agricultural Chemistry,

Faculty of Agriculture,

University of Tokyo,

Tokyo

Received October 25, 1969 